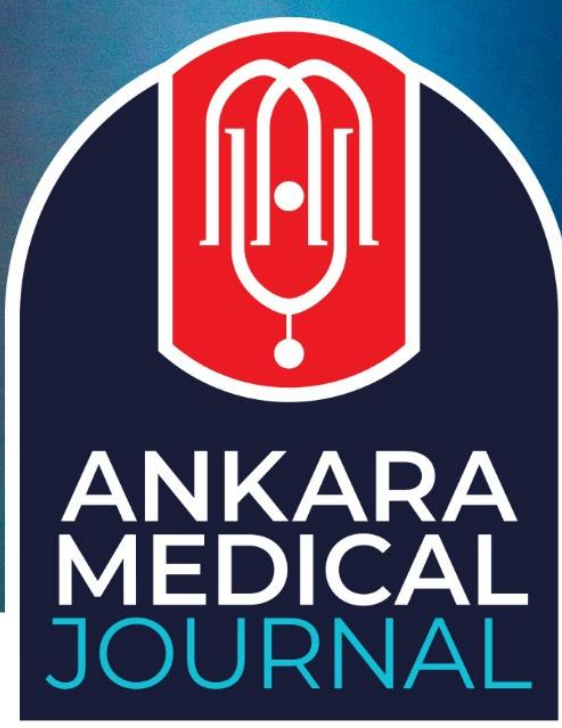

Case Report

Ankara Med J, 2020;(3):755-760 // (6o 10.5505/amj.2020.91069

\title{
WEGENER GRANULOMATOSIS UNDERLYING FIXED UPPER AIRWAY OBSTRUCTION
}

SABİT ÜST HAVA YOLU OBSTRÜKSİYONUNA YOL AÇAN WEGENER GRANÜLOMATOZU

\section{Durtuluş Aksu' ${ }^{1}$}

${ }^{1}$ University of Health Sciences Atatürk Chest Diseases and Chest Surgery Education and Research Hospital

Yazışma Adresi / Correspondence:

Kurtuluş Aksu (e-mail: kurtulusaksu@yahoo.com)

Geliş Tarihi (Submitted): 02.05.2020 // Kabul Tarihi (Accepted): 21.06.2020

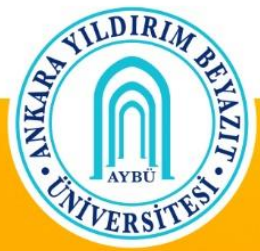

Ankara YIIdrrm Beyazıt University Faculty of Medicine 


\title{
Öz
}

Yıllardır astım tedavisi kullanan ancak tedaviden fayda görmeyen yetişkin bir kadında spirometrik değerlendirmenin inspiratuar ve ekspiratuar eğrilerinde düzleşme not edildi. İleri incelemelerde sabit üst hava yolu tıkanıklığının altında yatan patoloji olarak subglottik stenoz varlığı tespit edildi.

Anahtar Kelimeler: Sabit üst hava yolu obstrüksiyonu, spirometri, Wegener granülomatozu, mekanik dilatasyon.

\begin{abstract}
In an adult female who has been using asthma treatment for years but has not benefited from the treatment, flattening was noted in the inspiratory and expiratory curves of spirometric evaluation. Subsequent examination revealed the presence of subglottic stenosis as the underlying pathology of fixed upper airway obstruction.
\end{abstract}

Keywords: Fixed upper airway obstruction, spirometry, Wegener granulomatosis, mechanical dilatation. 


\section{Introduction}

Subglottic stenosis is defined as complete or partial stenosis in the subglottic area just below the vocal cords. ${ }^{1,2}$ It is a very rare disease and it is very difficult to diagnose and treat it. In most cases, the cause is acquired and associated with a history of intubation. ${ }^{3}$ However, as in the presented case, autoimmune diseases, especially Wegener's Granulomatosis, may cause this condition. ${ }^{3,4}$

In spirometric evaluation, fixed upper airway obstruction is presented with the characteristic plateau in the inspiratory and expiratory curves of the flow-volume loop. ${ }^{5}$ For this reason, abnormal appearances in spirometric curves should be considered clinically and further investigations should be performed in terms of underlying organic pathologies.

\section{Case Report}

A twenty-four year old female admitted to an immunology and allergy clinic due to uncontrolled asthma. Her symptoms ongoing despite regular asthma treatment with high dose inhaled corticosteroid and long-acting $\beta 2$ agonist. Her complaints were dyspnea, cough, sneezing, runny nose, and itchy eyes. In her physical examination, she was dyspneic and she had stridor. Auscultation of the chest revealed a reflection of stridor on lung fields while no rales or rhonchi. Spot scars were present in both legs of the patients. The body mass index was $22.0 \mathrm{~kg} / \mathrm{m}^{2}$. She was a non-smoker and defined no environmental and occupational exposure.

She had been followed in a chest disease clinic due to pulmonary mass lesion however no pathological diagnosis and no specific diagnosis were established with the interventional studies. The biopsy of scars in the legs was not performed. Perinuclear anti-neutrophil cytoplasmic antibodies ( $\mathrm{p}$-ANCA) were studied and found to be positive. Paranasal sinus tomography did not reveal any specific pathology.

Skin prick tests revealed hypersensitivity to pollens. A spirometric evaluation performed with ZAN 100 Spirometer, nSpire Health, Germany revealed forced expiratory volume in one second (FEV 1 ):54\%, forced vital capacity (FVC):88\%, FEV 1 /FVC:53\%. Flattening was noticeable on the curves of inspiration and expiration (Figure 1). The post-bronchodilator reversibility test was negative. Asthma treatment was discontinued because she did not benefit from asthma treatment clinically and spirometric examination does not support asthma. Treatment for seasonal allergic rhinitis was started due to her complaints; such as the runny nose and itchy eyes, and prick test results compatible with allergic rhinitis. She was referred to otorhinolaryngology and rheumatology clinics for further evaluations to elucidate pathology causing fixed upper airway obstruction. 
She was diagnosed as Wegener granulomatosis in the rheumatology clinic and systemic corticosteroid together with azathioprine treatment was started. Moreover, mechanical laser dilatation was performed in the otorhinolaryngology clinic for subglottic stenosis. Her complaints of dyspnea and stridor improved significantly after the dilatation of the subglottic area. Control spirometric evaluation was performed to assess inspiratory and expiratory flow rates. Unlike the flattening observed in inspiratory and expiratory curves before mechanical dilatation, the curves were observed to be almost completely normal (Figure 2).

Written consent was obtained from the patient.

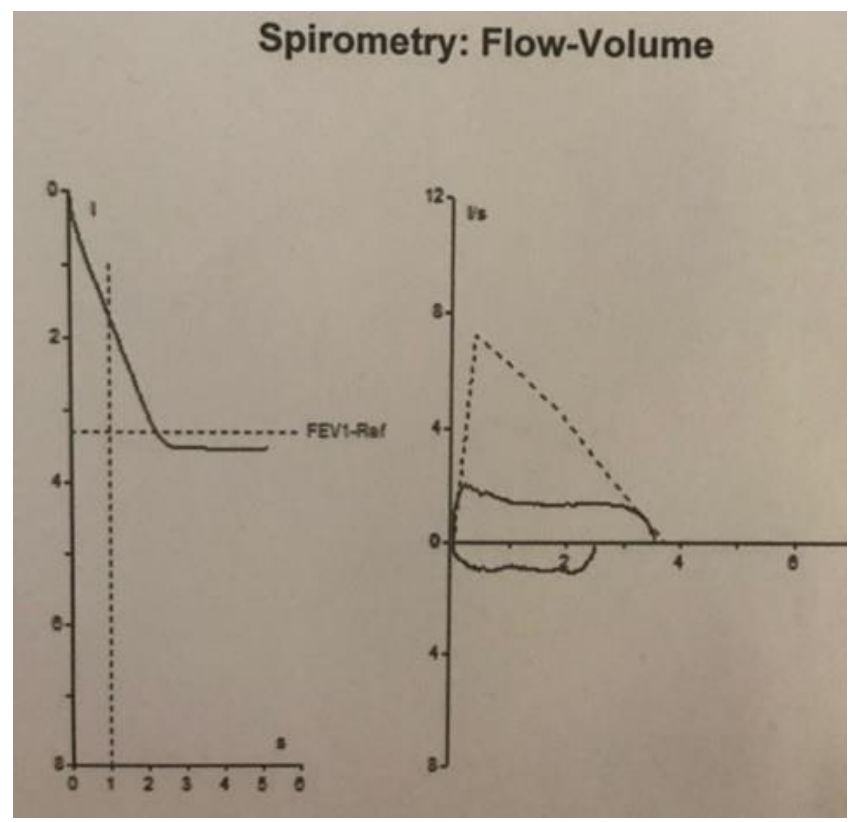

Figure 1. Spirometric curve reveals fixed upper airway obstruction.

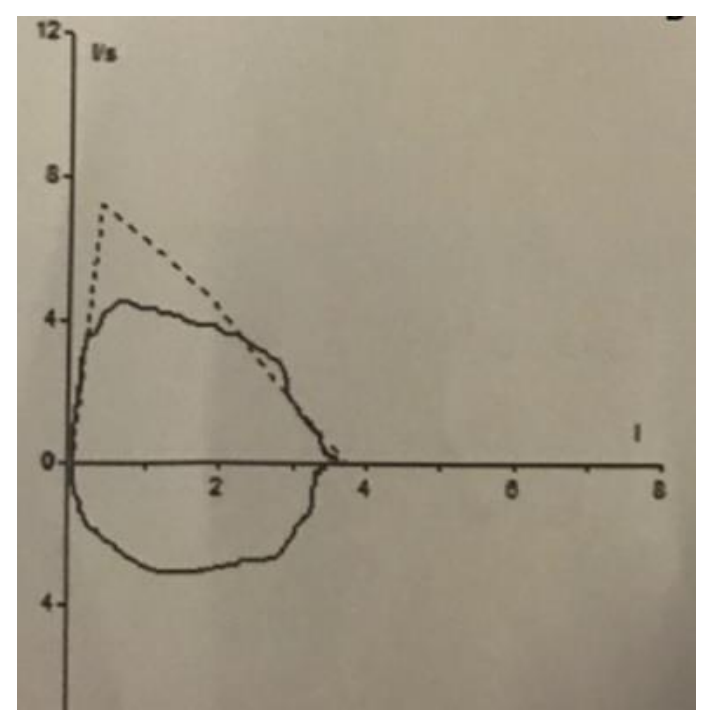

Figure 2. Spirometric evaluation after mechanical dilatation of subglottic stenotic area. 


\section{Discussion}

Many clinicians focus only on the quantitative values and \% values of FEV1, FVC, and FEV1 / FVC ratio in pulmonary function tests. However, volume-time and flow-volume curves should first be evaluated for a test suitable for the technique. According to these evaluations, differential diagnoses such as fixed upper airway obstruction, variable intra- or extra-thoracic obstruction can be made. Accordingly, this approach will enable the establishment of rare conditions such as Wegener Granulomatosis. ${ }^{6}$

The most common symptoms in subglottic stenosis are shortness of breath, cough, and stridor. Symptoms usually appear when stenosis rises above $50 \%$, that is, advanced stages of the disease. ${ }^{3}$ Langford et al. monitored patients with Wegener granulomatosis for twenty-two years and showed that 43 of 189 patients developed subglottic stenosis in their study. In their cohort the most common symptom detected was dyspnea with a rate of $79 \%$. The age of diagnosis of subglottic stenosis was found to be 26 (13-66) years. Among 37 patients whose ANCA test was studied 35 were found to be ANCA-positive. While 30 of these 35 ANCA-positive cases were cytoplasmic ANCA (c-ANCA) positive, 5 of them were p-ANCA positive. According to their results, they concluded that subglottic stenosis should be considered as a differential diagnosis in patients with Wegener granulomatosis with dyspnea. The presence of stridor is a crucial clue for the diagnosis of stenosis, but it is not present in every patient. Subglottic stenosis is best diagnosed by tracheal imaging performed by an otolaryngologist. ${ }^{4}$ The present case is also interesting because it is characterized by p-ANCA positivity seen at a maximum of $20 \%$, but not c-ANCA, which is considered very specific for Wegener's granulomatosis. ${ }^{7}$

In these patients, shortness of breath and cough are the most common symptoms, and erroneous evaluation of stridor as rhonchi in the physical examination may lead to false asthma diagnosis. ${ }^{8,9}$

Failure to consider the diagnosis of subglottic stenosis in these patients and the initiation of asthma treatment may lead to delay in diagnosis. ${ }^{9}$ In the treatment of Wegener granulomatosis-related subglottic stenosis, tracheal mechanical dilation and accompanying immunosuppressive regimens are essential for the relief of dyspnea. ${ }^{3,4}$

Although it is important to evaluate every patient in terms of asthma for family physicians in the field, it is an important overdiagnosis problem that family physicians, internists, and chest diseases physicians can treat each case with breathlessness by looking at it. This false diagnosis of "asthma" may delay other pathologies such as collagen tissue diseases and even lung cancer. 


\section{Key points}

- Rate of misdiagnosis of non-asthmatic pathologies as uncontrolled asthma is quite high.

- A detailed clinical history is mandatory for all patients and diseases that mimic asthma should be excluded.

- The abnormal views observed in spirometric flow-volume curves should be taken into consideration and further examinations including assessment of upper airway by otolaryngologists should be made in terms of organic pathologies that may lie beneath. 


\section{References}

1. Valdez TA, Shapshay SM. Idiopathic subglottic stenosis revisited. Ann Otol Rhinol Laryngol. 2002;111(8):690-5.

2. McCaffrey TV. Classification of laryngotracheal stenosis. Laryngoscope. 1992;102(12 Pt 1):1335-40.

3. Aravena C, Almeida FA, Mukhopadhyay S, et al. Idiopathic subglottic stenosis: a review. J Thorac Dis. 2020;12(3):1100-11.

4. Langford CA, Sneller MC, Hallahan CW, et al. Clinical features and therapeutic management of subglottic stenosis in patients with Wegener's granulomatosis. Arthritis Rheum. 1996;39(10):175460.

5. Pellegrino R, Viegi G, Brusasco V, et al. Interpretative strategies for lung function tests. Eur Respir J 2005: 26:948- 68 .

6. Miller MR, Hankinson J, Brusasco V, et al; ATS/ERS Task Force. Standardisation of spirometry. Eur Respir J. 2005;26(2):319-38.

7. Radice A, Sinico RA. Antineutrophil cytoplasmic antibodies (ANCA). Autoimmunity. 2005;38(1):93103.

8. Aaron SD, Vandemheen KL, FitzGerald JM, et al. Reevaluation of Diagnosis in Adults With PhysicianDiagnosed Asthma. JAMA. 2017;317(3):269-79.

9. Aksu K, Aksu F, Uçar A, Erdoğan A, Yılmaz YF. Yanlış Astım Tanısı: Erişkin Yaşta Tanı Almış Konjenital Subglottik Stenoz. CBU-SBED, 2015, 2(2):47-9. 